\title{
Visitor profiling using characteristics of socio-demographic and spatial behavior as tools to support the management of protected mountain areas
}

JURAJ ŠVAJDA ${ }^{1}$, MATEJ MASNÝ ${ }^{1}$, SAMUEL KORÓNY $^{1}$, ADALBERT MEZEI $^{2}$, IVO MACHAR ${ }^{3}$, KAROLINA TACZANOWSKA ${ }^{4}$

${ }^{1}$ Matej Bel University (MBU), Banská Bystrica, Slovakia; e-mail: juraj.svajda@umb.sk

${ }^{2}$ Low Tatras National Park Administration, Banská Bystrica, Slovakia

${ }^{3}$ Palacký University, Olomouc, Czechia

${ }^{4}$ University of Natural Resources and Life Sciences (BOKU), Vienna, Austria

ABSTRACT Protected mountain areas are attractive tourist destinations, and the number of visitors to these areas is increasing. The extension of cable car operations into the summer season is a challenge for some protected areas. Our study focuses on visitor profiles and is based on the characteristics of socio-demographic and spatial behavior of cable car users of the Chopok area (Slovakia). The methods used involve recording visitors' itineraries through the use of GPS loggers and conducting post-trip interviews with the study participants. In order to better understand visitors' spatial behavior, the relationship between socio-demographic characteristics and trip itinerary parameters was analyzed. Additionally, three distinct visitor profiles based on cluster analysis were found in the investigated sample. The results can be used to enrich our knowledge concerning the spatial behavior of tourists in mountain environments, and more directly, for the management of cable car destinations located within protected areas.

KEY WORDS GPS-tracking - tourism - outdoor recreation - visitor profile - spatial behavior Low Tatras National Park - cable car

ŠVAJDA, J., MASNÝ, M., KORÓNY, S., MEZEI, A., MACHAR, I., TACZANOWSKA, K. (2018): Visitor profiling using characteristics of socio-demographic and spatial behavior as tools to support the management of protected mountain areas. Geografie, 123, 4, 461-478.

Received February 2018, accepted November 2018.

C Česká geografická společnost, z. s., 2018 


\section{Introduction}

National parks are the best understood and most visited protected areas, and they are managed primarily to protect natural biodiversity. They are also important as they provide opportunities for education and recreation (Worboys et al. 2015). Visits to protected areas are increasing globally and in many regions, including Europe, research on visits is also increasing (Pickering et al. 2018). The research includes studies into new methods and technologies and how they can enhance sustainable decision-making. Tourism and recreational activities can be considered as inherent elements of human influence on biodiverse areas, especially in mountains. As places with high aesthetic and natural values mountains are often a source of interest for tourism and recreation. They should be taken into consideration in the management and planning of protected areas and adjacent lands. The tourist industry is certainly important from an economic and regional point of view. On the other hand, tourism has significant negative environmental impacts (Hammitt, Cole, Monz 2015). One challenging activity inside protected areas is the operation of cable cars. Their impact on adjacent natural areas is often more important than the impact of more general tourism activities further away - e.g. the impact on water, fauna and flora, including habitat reduction and fragmentation (Pickering, Harrington, Worboys 2003). Other effects come from the attractive range of opportunities available for sports (skiing) and accommodation (hotels), both of which may lead to higher numbers of visitors to an area. If the landscape and national parks were transformed into holiday resorts with a significant extension of ski slopes and other recreational facilities, the socio-economic composition of the visitors might also change (Getzner, Švajda 2015).

Geography and tourism have always been connected. Human behavior in time and space is affected by a range of physical, social and economic settings (Golledge, Stimson 1996). Already the Tobler's First Law of Geography states that "everything is related to everything else, but near things are more related than distant things" (Tobler 1970) and may be also applied in tourism context, explaining use intensity within specific tourist destinations. A related term "friction of distance", which describes the force that creates distance decay, is being used to explain the effect of distance on many cultural or spatial interactions (Fouberg, Murphy, Blij 2015). This framework is often applied in transportation research to explain pedestrian traffic in urban environments (Acton 2013), but could be also relevant in outdoor recreation settings. Human mobility patterns can be also well explained by the concepts of time geography. Hägerstrand (1970) introduces temporal aspects to spatial behavior of individuals and underlines the existence of temporal constrains in the context of human mobility. According to his work the individual describes a path in time-space within a situational context. Therefore, phenomena such as movement of individuals in space are largely affected 
by temporal constrains. Within the field of behavioral geography Golledge (2001) distinguishes between studying "human spatial behavior" and "human behavior in space". While the first term refers to the analysis of moving objects, the second one involves social component, such as decisions and their determinants behind overt actions of people in space.

Research into tourists' attitudes and behavior, especially in mountain environments, through the use of new technology, is becoming increasingly popular. Current studies (Hardy et al. 2017; Shoval, Ahas 2016; Shoval, Isaacson, Chhetri 2013) deal with the theoretical and methodological aspects of the use of tracking technologies in research into the time-space behavior of tourists. The subject of the research is often an analysis of the patterns of the time-space behavior of tourists in mountains in relation to classical concepts of time-geography - i.e. relationships between time-space constraints and spatial patterns (Bauder 2015; Petterson, Zillinger 2011). Other approaches allow researchers to map the intensity of use of different routes (visitor flows) based on the preferences of tourists. This research is done in terms of the implications for sustainable development and destination management (Edwards, Griffin 2013; Meijles et al. 2014; Wolf, Hagenloh, Croft 2012; Bielański et al. 2018; Taczanowska et al. 2014), and for the creation of innovative tourist typologies (Beeco et al. 2013; Shoval et al. 2015; Grinberger, Shoval, Mc Kercher 2014; Hallo et al. 2012).

The operation of cable cars and other transport facilities in mountain areas is often associated with winter tourism, especially skiing. However, operators see great potential in extending the seasonal availability of cable cars to a yearround operation (Richins, Hull 2016). In protected areas characterized by greater vulnerability of the natural environment, it is necessary to consider limiting traffic in order to reduce potential environmental impacts. An understanding of visitor behavior (Taczanowska et al. 2016) and visitor profiles (Hibner et al. 2018) near cable car infrastructure is essential for the efficient management of these areas. The application of appropriate techniques to monitor visits makes it possible to obtain complex information and characteristics (Cessford, Muhar 2003). GPS tracking is one of the most commonly used methods for tracking moving objects, including people (Shoval, Isaacson 2007). It is helpful for obtaining accurate information on the spatial aspects of visitor behavior in order to balance human use and its impact with the protection of natural resources (Korpilo et al. 2018). Comprehensive knowledge about visitor motivation is also important for the daily management of protected areas. The current literature describes categorizing visitors based on willingness to pay (Oliveira et al. 2017), recreational activities (Barić, Anić, Bedoya 2016), national-park affinity (Arnberger et al. 2012) or acceptability norms (Marin et al. 2011). A wide variety of studies focus on the motivations and expectations of visitors (Needham et al. 2011; Marques, Reis, Menezes 2010). 
The main purpose of our study was to explore the profiles of visitors to the cable car destination located at Chopok in the Low Tatras National Park and to better understand the relationships between the tourists' motivations, their sociodemographic characteristics and their spatio-temporal behavior.

\section{Study area}

The study area is located in the Low Tatras National Park, where the third degree of territorial protection is in place, in compliance with national legislation. The National Park was established in 1978 and covers an area of $728 \mathrm{~km}^{2}$ in central Slovakia. The park area is part of the Natura 2000 network (special protection areas and sites of community importance). Small scale protected areas (e.g. the national nature monument Vrbické lake, the national nature reserve Demänovská valley) and the Ramsar site Demänovské caves are also located here.

The Jasná resort located in the northern part of the national park is the largest skiing area in Slovakia. Chopok (2,024 $\mathrm{m}$ a.s.l.) is the third highest mountain in the Low Tatras NP. The peak offers a panoramatic view and is one of the most popular destinations in the region. Chopok can be reached by cable car and hiking trails.

The first part of the infrastructure was built in 1958 prior to the establishment of the national park and over the last decade it has been modernized and enlarged. Over the past 10 years many authors (e.g. Krtička, Tomčíková, Rakytová 2018) have stated that the development of tourism in the Demänovská valley is related to the construction of cable cars, ski lifts, ski slopes and accommodation, all of which has resulted in a growing number of visitors. Extensive improvements of the old technical facilities and the connection between north and south since 2005 has made the whole area more attractive for tourism. This has had an intense impact on the natural environment - e.g. significant changes in the structure and species within the phytocenoses (Barančok, Barančoková 2003).

Hiking trails and attendance are two of the causes of the increased devastation of the high mountain landscape (Hrnčiarová 2014). The increasing transport capacity and the cable car operation in the summer months mean that tourists have easy access to the top of Chopok, which has resulted in a significant increase in visits. Systematic visitor monitoring data are missing and only data from occasional quantitative visitor surveys are available (e.g. Piscová et al. 2018). Besides hiking trails, visitors can use the Rotunda restaurant at the summit and enjoy the various attractions offered by the resort (e.g. mountain carts). 


\section{Methodology}

The study was conducted from August $29^{\text {th }}$ to August $31^{\text {st }}, 2017$ in the Priehyba area - Chopok (return ticket holders were interviewed at the bottom station of the Funitel cable car). The overall number of journeys taken on the Funitel cable car during the days of the survey was 8,465 (a slightly higher number of people took the cable car up as some did not return to the bottom with typical daily flow of visitors - see Figure 3).

In order to investigate the spatio-temporal behavior of visitors and their sociodemographic characteristics, a combination of two data collection methods was applied: recording the visitors> routes using GPS loggers (Holux with settings criteria for pedestrians log every 4 seconds and 10 metres) and interviewing them after their journeys using a short, structured questionnaire (Paper and Pencil Interviewing technique). At fixed intervals (random systematic sampling) trained interviewers selected participants travelling by cable-car at the beginning of their trips and distributed GPS loggers to those who had return tickets (acceptance rate $95 \%)$. After returning from their trips the study participants were asked to complete the questionnaire. The recorded trip itineraries (GPS-tracks) were transferred by Holux ez Tour software and analyzed and processed in the ArcGIS 10.2 programming environment. Spatial Analyst and Tracking Analyst extensions were used for spatial analysis. In order to analyze the collective behavior of visitors within the area, the Kernel density algorithm was used to calculate the GPS-trackpoints> density (calculation settings: $50 \mathrm{~m}$ search radius; units: square $\mathrm{km}$; raster resolution: $10 \mathrm{~m}$ ).

The visitors' movement parameters (e.g. trip distance and time) were then linked to the visitor characteristics based on the results of the questionnaires (e.g. frequency and motivation for visit, age, number of people in group). By using the statistical software IBM SPSS we aimed to find a reasonable typology of visitors through a two step cluster analysis with several variables. A total of 196 questionnaires and 197 tracking logs were collected during three days of full traffic with ideal sunny weather. Some questionnaires were not completed fully and were excluded from further analysis $(n=190)$.

\section{Results}

\subsection{Socio-demographic characteristics of visitors}

The proportion of visitors was $63 \%$ men and $37 \%$ women. Most visitors were from Slovakia (74\%) and others were from Czechia, Poland and Israel. Regarding educational levels, most visitors had completed secondary school (52\%) or had a 
Table 1 - Statistical characteristics of visitors based on survey data

\begin{tabular}{lrrrrc}
\hline Variable/Parameter & Mean & Median & Std. dev. & Minimum & Maximum \\
\hline Frequency of visit & 2.26 & 2.00 & 1.166 & 1 & 4 \\
Length of stay (days) & 3.94 & 4.00 & 2.137 & 1 & 14 \\
Age & 42.41 & 40.00 & 12.044 & 18 & 77 \\
No. of adults & 2.61 & 2.00 & 3.238 & 1 & 45 \\
No. of children & 0.91 & 1.00 & 1.104 & 0 & 6 \\
\hline
\end{tabular}

Table 2 - Movement parameters based on the recorded GPS-tracks

\begin{tabular}{lrrccc}
\hline Variable/Parameter & Mean & Median & Std. dev. & Minimum & Maximum \\
\hline Trip time in hours & 3.97 & 3.70 & 1.920 & 0.50 & 8.82 \\
Trip distance in kms & 12.21 & 12.65 & 4.532 & 4.7 & 24.8 \\
Walking distance in kms & 6.35 & 4.85 & 4.338 & 0.5 & 18.2 \\
\hline
\end{tabular}

university degree (47\%). The median of frequency of visits was 2 (this means a visit every two years). Half of the visitors stayed for up to four days. The median age was 40 (Table 1). Half of the visitor groups were made up of two adults and one child. When asked about the main motivation for their visits, the respondents

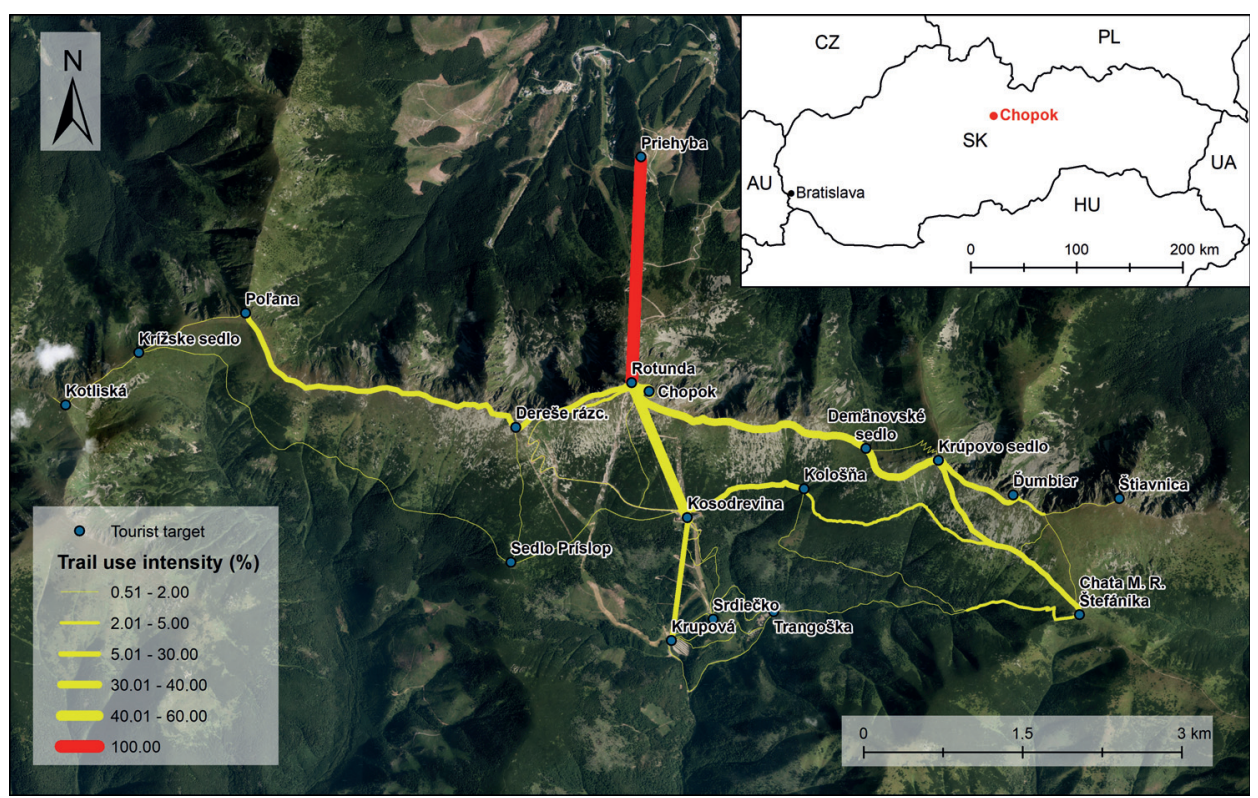

Fig. 1 - Most frequent visitor destinations and use of individual visitors' routes recorded using GPS (based on our own investigation, $n=190$, Chopok area, $29^{\text {th }}-31^{\text {st }}$ August 2017) 
could choose from a number of options and chose recreation (51\%), nature (49\%), staying with family or friends (44\%) and sport (30\%). For the vast majority of respondents $(62 \%)$, the fact that it is a protected area is irrelevant when deciding to visit this territory. Most respondents considered the number of visitors to Chopok to be reasonable (58\%), but a relatively large group (31\%) thought the number was rather large.

\subsection{Spatio-temporal behavior of visitors in the study area}

Median trip time was 3 hours and 42 minutes. In relation to trip distance (including cable-car transport), half of the visitor groups passed up to $12.65 \mathrm{~km}$. Median walking distance (without cable-car transport) was almost $5 \mathrm{~km}$ (Table 2). 41\% of visitors used the cable-car transport on the southern side of Chopok, probably because of the better price (Chopok package two-way North \& South). The most frequent destinations were Chopok (55\%), followed by Ďumbier (29\%) and Štefánik's hut, Pol'ana, Srdiečko and Kotliská (6 to 1\%) - see Figures 1-3.

4.3. Visitor profiles based on socio-demographic characteristics and movement parameters

One objective of our study was to find a reasonable typology of visitors through cluster analysis (statistical software IBM SPSS). The twostep cluster algorithm has

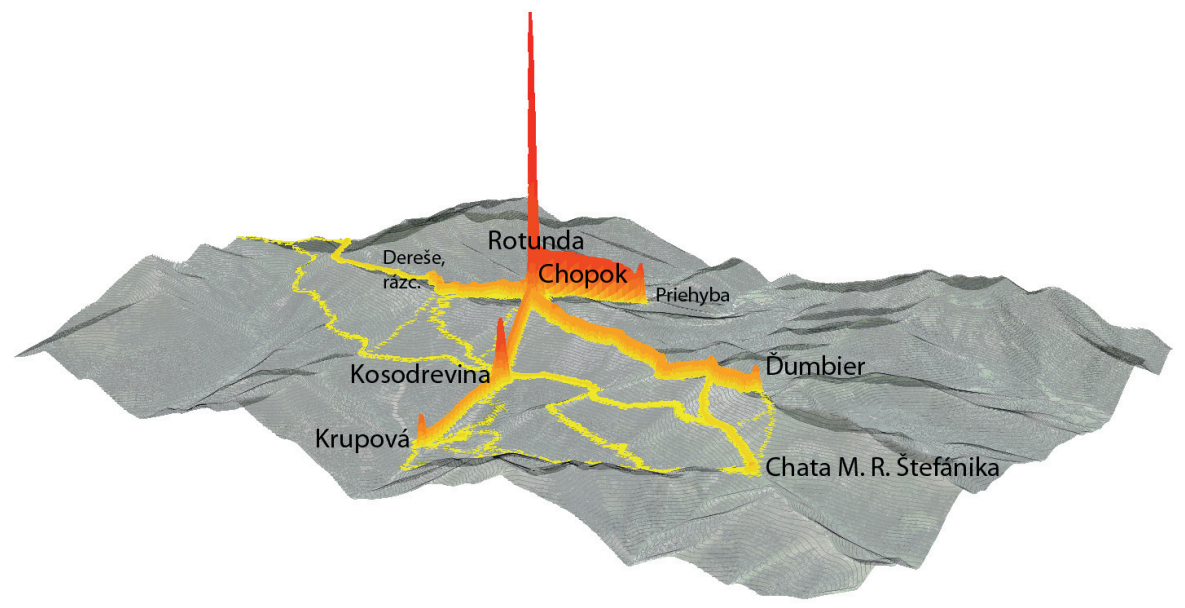

Fig. 2 - Most frequent visitor destinations and use of individual visitors' routes recorded using GPS results of the Kernel density analysis based on the recorded GPS trackpoints ( $n=190$ trip itineraries; 508,999 trackpoints) 

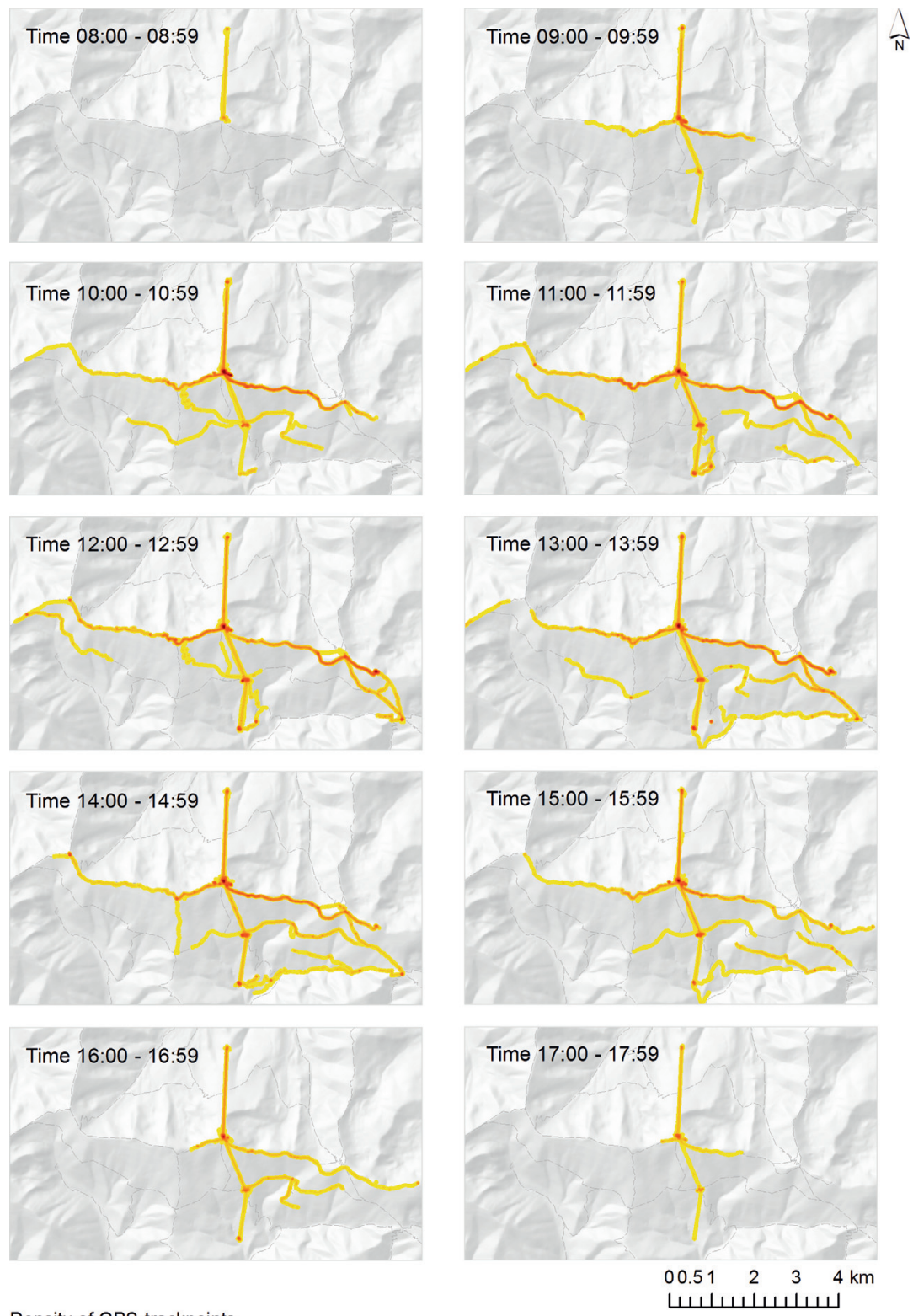

Density of GPS-trackpoints [Kernel density; per sq km]

\begin{tabular}{|c|c|c|c|}
\hline $1-5000$ & $50001-100000$ & $500001-750000$ & Marked trails \\
\hline $5001-10000$ & $100001-150000$ & $750001-1000000$ & \\
\hline $10001-25000$ & $150001-250000$ & $1000001-2000000$ & \\
\hline $25001-50000$ & $250001-500000$ & $2000001-3292779$ & \\
\hline
\end{tabular}

Fig. 3 - Spatial and temporal changes in recreational use intensity during the day; results of the Kernel density analysis based on the recorded GPS trackpoints ( $n=190$ trip itineraries; 508,999 trackpoints) 
Table 3 - Cross table of motivation vs. cluster membership

\begin{tabular}{|c|c|c|c|c|c|}
\hline \multicolumn{6}{|c|}{ Sport motivation } \\
\hline Answer & Parameter & 1 & 2 & 3 & Total \\
\hline \multirow[t]{2}{*}{ No } & Count & $0 a$ & $62 b$ & $70 b$ & 132 \\
\hline & $\%$ within Cluster & $0.0 \%$ & $100.0 \%$ & $100.0 \%$ & $69.5 \%$ \\
\hline \multirow[t]{2}{*}{ Yes } & Count & $58 a$ & ob & ob & 58 \\
\hline & $\%$ within Cluster & $100.0 \%$ & $0.0 \%$ & $0.0 \%$ & $30.5 \%$ \\
\hline \multirow[t]{2}{*}{ Total } & Count & 58 & 62 & 70 & 190 \\
\hline & $\%$ within Cluster & $100.0 \%$ & $100.0 \%$ & $100.0 \%$ & $100.0 \%$ \\
\hline \multicolumn{6}{|c|}{ Social motivation (time spent with family or friends) } \\
\hline Answer & Parameter & 1 & 2 & 3 & Total \\
\hline \multirow[t]{2}{*}{ No } & Count & $44 a$ & $62 b$ & oc & 106 \\
\hline & $\%$ within Cluster & $75.9 \%$ & $100.0 \%$ & $0.0 \%$ & $55.8 \%$ \\
\hline \multirow[t]{2}{*}{ Yes } & Count & $14 a$ & ob & $70 c$ & 84 \\
\hline & $\%$ within Cluster & $24.1 \%$ & $0.0 \%$ & $100.0 \%$ & $42.2 \%$ \\
\hline \multirow[t]{2}{*}{ Total } & Count & 58 & 62 & 70 & 190 \\
\hline & $\%$ within Cluster & $100.0 \%$ & $100.0 \%$ & $100.0 \%$ & $100.0 \%$ \\
\hline
\end{tabular}

found three clusters - the clusters are roughly the same size (Table 3), based on two nominal variables; sport motivation and social motivation are more important than the other four scale variables (number of children, walking distance, trip distance and trip time).

When we analyze the variables involved in detail, associations between nominal variables and cluster membership can be found. Table 3 shows an association between sport motivation and cluster membership. The Fisher test is significant $(\mathrm{p}<0.001)$. The small letters behind the absolute counts are the outputs of the APA style. We can see that the proportion of positive answers in cluster 1 is different from the proportions in the other two clusters. This is the cause of the significance.

The cause of the association between social motivation and cluster membership is more complicated (Table 3 ). The Fisher test is again significant $(\mathrm{p}<0.001)$. From APA notation we see that all three proportions are mutually exclusive. If we consider the ascending proportion of positive answers, then the proportion $(0 \%)$ in cluster 2 is smaller than in clusters 1 and 3 . The proportion of positive answers $(24.1 \%)$ in cluster 1 falls between the proportions in clusters 2 and 3 . The proportion of positive answers $(100 \%)$ in cluster 3 is significantly larger than in clusters 1 and 2 .

The differences in the clusters, from the viewpoint of the scale variables involved, can be shown either in tables or graphs. In Table 4 we present the basic statistical characteristics of clusters and the results of the nonparametric Wilcoxon test on two samples. From the table it is clear that the differences among clusters are highly significant and this is also the case with the scale questionnaire variables involved $(\mathrm{p}<0.001)$. The median of the number of children is larger in 
Table 4 - Statistical characteristics of scale questionnaire variables involved

\begin{tabular}{llcccc}
\hline Cluster & Parameter & No. of children & Trip time (hours) & Trip dist $(\mathrm{km})$ & Walk dist $(\mathrm{km})$ \\
\hline 1 & Mean & 0.520 & 5.010 & 14.810 & 8.960 \\
& Median & 0.000 & $5.330^{* * *}$ & $15.050^{* * * *}$ & $10.100^{* * *}$ \\
& Std. dev. & 0.843 & 1.805 & 4.353 & 4.105 \\
\hline 2 & Mean & 0.520 & 3.620 & 11.370 & 5.480 \\
& Median & 0.000 & 3.120 & 11.900 & 4.150 \\
& Std. dev. & 0.987 & 1.872 & 4.292 & 3.994 \\
\hline 3 & Mean & 1.570 & 3.410 & 10.800 & 4.970 \\
& Median & 1.000 & 3.230 & 10.950 & 3.450 \\
& Std. dev. & 1.084 & 1.720 & 4.002 & 3.895 \\
\hline
\end{tabular}

Note: ${ }^{* * *} p<0.001$

cluster 3 than in clusters 1 and 2. The three other scale variables (trip time, trip distance and walking distance) have larger medians in cluster 1 relative to clusters 2 and 3.

Cluster 1 is different to clusters 2 and 3 only in the positive (proportion 100\%) answers to sport motivation. Negative answers predominate (proportion $75.9 \%$ ) in social motivation. In the case of scale variables it has a smaller number of children in the group and significantly larger values for the three other scale variables involved: walking distance, trip distance and trip time. Visitors in cluster 2 all answered negatively for both involved motivations (proportion 100\%). All scale variables are characterized by smaller values. Cluster 3 is characterized by only negative (proportion 100\%) answers to sport motivation and by only positive (proportion 100\%) answers to social motivation. In the field of scale questionnaire variables, cluster 3 has a larger number of children (mean $=1.57)$. The other three scale variables contain rather smaller values.

Finally we can present a qualitative typology for the three clusters. Cluster 1 can be labelled as sport-oriented visitors with full engagement in sport (see also larger values for the three distance and time variables). Cluster 2 (casual visitors) is characterized by no sport and social motivation. Scale variables are rather small (probably this group includes visitors who want to be alone and to relax in the countryside without making a big effort). Cluster 3 (family and friends-oriented visitors) contains family groups with more children and social motivation.

Figure 4 presents the spatial distribution of each cluster group in the study area. The representatives of cluster 1 use a wide range of trails, not only the paths located along the main mountain ridge but also numerous trails on the southern face of the mountain range. The other extreme is represented by cluster 3 , people staying in close proximity to the main cable-car station at Chopok and only using major trails along the ridge (e.g. trail to Dereše, rázc., Demänovské sedlo, Krúpovo 


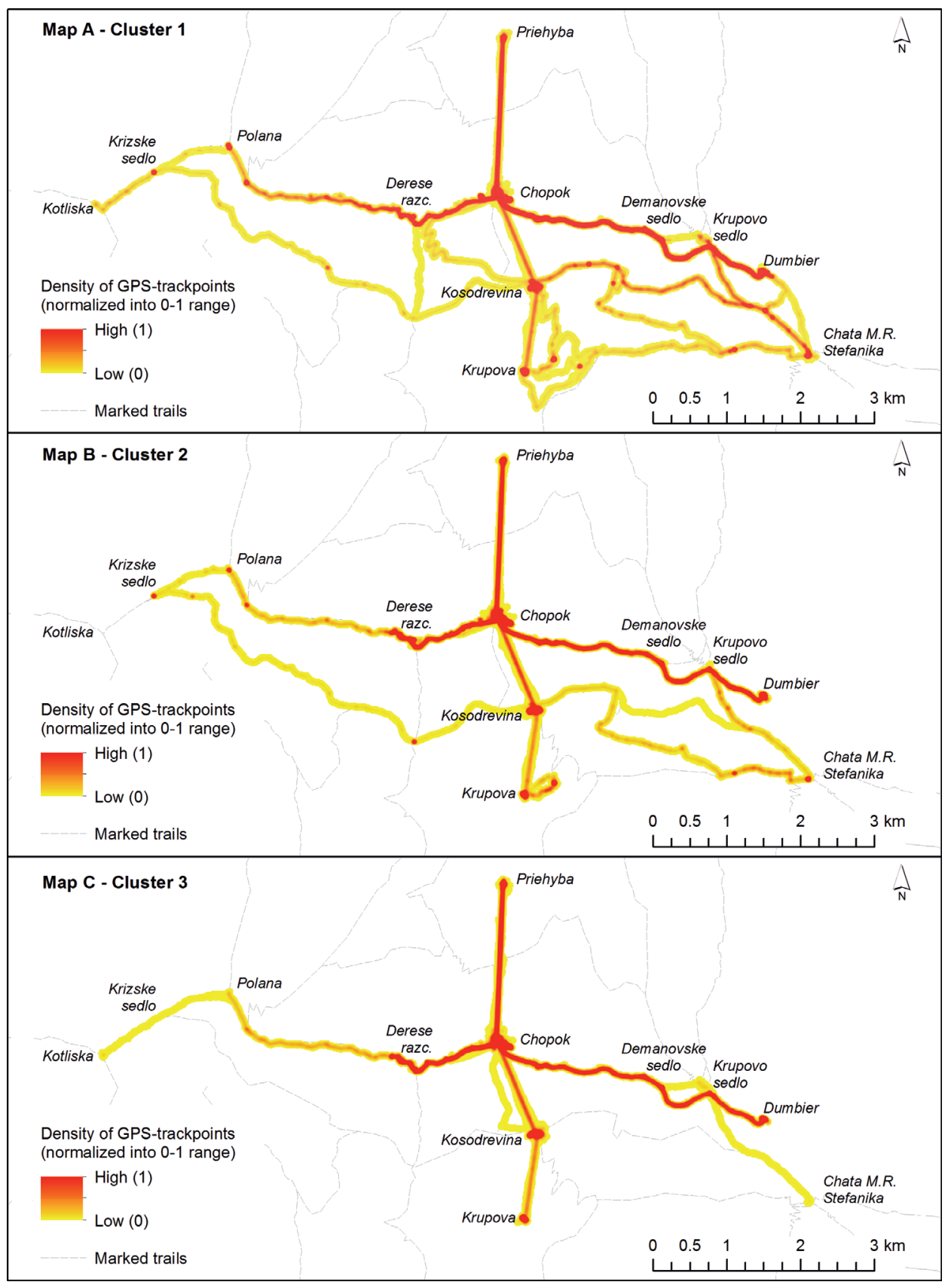

Fig. 4 - Spatial distribution of visitors grouped by clusters - results of the Kernel density analysis based on the recorded trackpoints (cluster 1: $n=58$ trip itineraries; 199,827 GPS trackpoints, cluster 2: $\mathrm{n}=62$ trip itineraries; 163,463 GPS trackpoints, cluster 3: $\mathrm{n}=70$ trip itineraries; 145,709 GPS trackpoints) 
sedlo or Dumbier). The casual visitors (cluster 2) also concentrate along the main ridge of the mountain, although some of them chose more distant trips around the Chopok area.

\section{Discussion and conclusions}

The aim of our paper was to find and explore the relationships between the sociodemographic characteristics and the spatio-temporal behavior of tourists as the basis for further visitor management. Our study has exclusively applied context, however from theoretical point of view, obtained results confirm concepts and frameworks explained in introduction. Presented results are compatible with well-established theories in the field of geography, such as Tobler's First Law of Geography (Tobler 1970) and time geography (Hägerstrand 1970). Recreational use intensity in Chopok area mirrors the concept of distance decay - the highest visitation is being observed close to the central location (Rotunda cable car station) and its value decreases with network distance. The observed pattern, especially the spatio-temporal changes in use intensity, may be well explained by movement trajectories of visitors and temporal constraints related to the cable car schedule and time budget of visitors. Understanding human movement and behavior in parks and protected areas is an integral part of managing social-ecological systems, in particular, the spatial travel patterns of tourists and their impacts on ecosystems (Stamberger et al. 2018). GPS-tracking is novel in the Carpathians - so far only one protected area has used it, so there is a clear benefit for the management of protected areas.

The study aimed to explore not only spatial behavior of visitors in general, but also to better understand the factors (socio-demographic characteristics) influencing behavior of tourists in Chopok area. Our results confirmed three distinct visitor profiles based on the importance of visitors' motivation; other variables have negligible influence. Factors such as the presence of marked trails and the distance to facilities explained visitor distributions. Patterns differ among respondent groups, which is also true for itinerary variables such as walking speed and trip time. Segmentation based on different characteristics is a useful research tool for producing a clear visitor profile and studying the relationship between a particular segmentation base and visitors' behavior and preferences. Our study didn't confirmed relation of different demographic data (Kruger, Viljoen, Saayman 2017), gender and age (Petrovic, Tomicevic-Dubljevic, Stavretovic 2016) or group size (Meijles et al. 2014) to the use of the area. Activity type and age could affect the spatial behavior of park visitors through the high physiological requirements of many outdoor recreational activities, especially in mountain areas (Schamel 2017). 
Our findings are consistent with the results of different authors (e.g. Manning, Anderson 2012) that certain areas in parks, including attraction sites, receive especially heavy visits. Since use is concentrated around facilities and services, these areas experience many resource and experiential impacts. As Bell (2008) stated, understanding how people use the natural environment is crucial in balancing the needs of visitors and capacities of sites. The main mountain ridge and the area close to the cable-car station were places which had large numbers of visitors. The problem will be more pressing in the future because of the sensitivity of these areas to climate change. The rapid development of mountain tourism worldwide over recent years has made the goal of sustainable mountain tourism even more challenging (Tsiaras 2017). Numerous alpine accommodation providers and ski operations have been significantly impacted by the issue of seasonality (Pegg, Patterson, Gariddo 2012) so we suppose that there will be an increase in the number of summer visitors every year also in our study area.

Understanding the opinions and preferences of visitors is one of the fundamental requirements when setting up an appropriate tourism management plan in a number of protected areas (Banaš, Zahradník 2012). Summer visitors give significant preference to the activities of soft tourism. The study area is a great example of how the continued expansion of the ski resorts and the requirements for new buildings has created pressures on the environment, particularly the protected areas. An assessment of the natural and anthropogenic risks to the site and a proposal for optimal land use (Špulerová et al. 2016) should include the prevention of future conflicts. Solutions used in other areas - e.g. Austria and France (Mayer, Mose 2017) range from a total ban on infrastructure development in favour of conservation, to the partial destruction of national parks. There is a legitimate question about the compatibility of such activities with the goals of national park management based on international criteria (Getzner 2009). The information policies of the national parks could be refined in this respect, including educational experiences for visitors focused on nature. Respondents stated that nature was one of the main motivations behind their visit, however the existence of protected areas was irrelevant for the majority when deciding to visit. This may indicate a low awareness of the existence of protected areas.

The sampling and the design of survey research are one of the most important areas of data collection (Sirakaya-Turk et al.2017) in applied research into leisure, recreation and tourism. This study enables comparisons between different areas and their visitors. Our results also mapped the baseline situation in the area and after replication it can be possible to study any potential shifts and trends in visitor segments, including their behavior. One of the limitations of our work could be the limited number of questions and the relatively small sample of respondents involved in the survey. However, that doesn't diminish the credibility of the findings. Further research could potentially also include cable-car non-users, involve 
a longer time spent gathering data and assessing the sample representativeness of summer visitors.

Documenting the spatial behavior of tourists via GPS-tracking has developed rapidly over the last 15 years (Shoval, Isaacson 2007; Shoval, Isaacson, Chhetri 2013; Bielański et al. 2018; Taczanowska et al. 2014). Tracking technologies have replaced traditional observation, trip diaries and map sketches (Cessford, Muhar 2003). The obvious benefit is in being able to record visitors' geographic positions associated with corresponding time stamps without the necessity of interfering with the respondents during the data collection process - the only requirement is their agreement to carry a GPS device. The resolution of the spatial and temporal data is very high in comparison to other visitor monitoring tools (Shoval, Isaacson 2007). However, this recent data collection method is not free of limitations. One of the major problems relates to the awareness of being tracked by the studied subjects (Beeco, Hallo 2014; D’Antonio et al. 2010; Taczanowska, Muhar, Brandenburg 2008). This fact can affect visitor behavior, such as staying on a designated trail, the distances travelled and the speed of movement. However, so far there is no evidence to support this hypothesis. Moreover, the response rate of our study was $95 \%$. Thus, the tourists we approached largely had a positive attitude to the study and were willing to participate in GPS-tracking and the survey. Another critical point in GPS-tracking might be the limited signal accuracy in unsuitable terrain conditions, especially in the mountain environments (Satomura et al. 2005). This could also be caused by an incorrectly carried GPS device (e.g. storage deep in a backpack). According to the producer of the device, the accuracy of Holux GPS loggers used in our study was estimated to be \pm 3 metres, but no comprehensive field experiments on the data accuracy of this device have been conducted in the study site. As the focus of the study was not related to very precise measurements such as off-trail usage in sensitive protected zones, the inaccuracy did not affect the results.

Tourism in the Chopok area is a dynamic phenomenon. The number of tickets sold and the construction of new infrastructure, including the connection of the north and south sides of the area have had a significant impact and have contributed to the increase in visits to the immediate surroundings of the top station. The individual movement of visitors is influenced in addition by the terrain, the infrastructure, the attractions and the information available. Cable-car areas in particular attract large number of visitors who are motivated more by social than natural aspects of the area. Our results also showed that $2 / 3$ of visitors to the study area are less active (trip time and distance is smaller). We found no significant relationships with other variables (knowledge that the area is protected, perception of crowding). These results can serve the management of the national park as well as cable-car operators in managing the social and environmental impacts of tourism on Chopok, as a popular destination within the national park territory. 
The results can contribute to the observation of respect for tourist trail closures, conflict prevention, targeted routes and forms of communication among visitors' segments, along with an increased focus on hotspots due to the density of visitors. The results can be of benefit in the modelling of carrying capacity (ecological and social) along hiking trails, as well as in monitoring the negative impacts on the abiotic and biotic environment (the occurrence of rare plant and animal species) and the improved time management of employees working in the field.

\section{References}

ACTON, A. (2013): Issues in Transportation Research and Application: 2013 Edition. Scholarly Editions.

ARNBERGER, A., EDER, R., ALLEX, B., STERL, P., BURNS R. (2012): Relationships between national-park affinity and attitudes towards protected area management of visitors to the Gesaeuse National Park, Austria. Forest Policy and Economics, 19, 48-55.

BANAŠ, M., ZAHRADNÍK, D. (2012): Monitoring of the visitors' opinions in protected mountain areas in the Czech Republic (KRNAP, NP and PLA Šumava, PLA Jeseníky, PLA Beskydy). Public Recreation and Landscape Protection - With Man Hand in Hand, Conference Proceeding, Mendel University in Brno, 7-16.

BARANČOK, P., BARANČOKOVÁ, M. (2013): Development of sports and recreational activities in the Chopok area (Nízke Tatry Mts.) and protection of important landscape elements. Public Recreation and Landscape Protection - With Man Hand in Hand, Conference Proceeding, Mendel University in Brno, 27-35.

BARIĆ, D., ANIĆ, P., BEDOYA, A. (2016): Segmenting protected area visitors by activities: A case study in Paklenica National Park, Croatia. European Journal of Tourism Research, 13, 103-121.

BAUDER, M. (2015): Using GPS supported speed analysis to determine spatial visitor behaviour. International Journal of Tourism Research, 17, 4, 337-346.

BEECO, J.A., HUANG, W.J., HALLO, J.C., NORMAN, W.C., MCGEHEE, N.G., MCGEE, J., GOETCHEUS, C. (2013): GPS tracking of travel routes of wanderers and planners. Tourism Geographies, 15, 3, 551-573.

BEECO, J.A., HALLO, J.C. (2014): GPS Tracking of Visitor Use: Factors Influencing Visitor Spatial Behaviour on a Complex Trail System. Journal of Park and Recreation Administration, 32, $2,44-62$.

BELL, S. (2008): Design for Outdoor Recreation. Taylor \& Francis.

BIELAŃSKI, M., TACZANOWSKA, K., MUHAR, A., ADAMSKI, P., GONZÁLEZ, L.-M., WITKOWSKI, Z. (2018): Application of GPS tracking for monitoring spatially unconstrained outdoor recreational activities in protected areas - A case study of ski touring in the Tatra National Park, Poland. Applied Geography, 96, 51-65.

CESSFORD, G., MUHAR, A. (2003): Monitoring options for visitor numbers in national parks and natural areas. Journal for Nature Conservation, 11, 4, 240-250.

D’ANTONIO, A., MONZ, C., LAWSON, S., NEWMAN, P., PETTEBONE, D., COURTEMANCH, A. (2010): GPS-Based Measurements of Backcountry Visitors in Parks and Protected Areas: Examples of Methods and Applications from Three Case Studies, 38, 3, 42-60.

EDWARDS, D., GRIFFIN, T. (2013): Understanding tourists' spatial behaviour: GPS tracking as an aid to sustainable destination management. Journal of Sustainable Tourism, 21, 4, 580-595. 
FOUBERG, E.H., MURPHY, A.B., BLIJ, H.J.D. (2015): Human Geography: People, Place, and Culture, Revised. ed. John Wiley \& Sons Inc, Hoboken.

GETZNER, M. (2009): Economic and cultural values related to Protected Areas Part A: Valuation of Ecosystem Services in Tatra (PL) and Slovenský Raj (SK) national parks. Final report, WWF DCP Vienna, Austria.

GETZNER, M., ŠVAJDA, J. (2015): Preferences of tourists with regard to changes of the landscape of the Tatra National Park in Slovakia. Land Use Policy, 48, 107-119.

GOLLEDGE, R.G., STIMSON, R.J. (1997): Spatial Behaviour: A Geographic Perspective. The Guilford Press, New York, USA.

GOLLEDGE, R.G. (2001): Behavioural Geography. International Encyclopedia of the Social \& Behavioural Sciences. Elsevier Science Ltd. 1105-1111.

GRINBERGER, A.Y., SHOVAL, N., MC KERCHER, B. (2014): Typologies of tourists' time-space consumption: a new approach using GPS data and GIS tools. Tourism Geographies, 16, 1, 105-123.

HALLO, J.C., BEECO, J.A., GOETCHEUS, C., Mc GEE, J., Mc GEHEE, N.G., NORMAN, W.C. (2012): GPS as a method for assessing spatial and temporal use distributions of nature-based tourists. Journal of Travel Research, 51, 5, 591-606.

HAMMITT, W.E., COLE, D.N., MONZ, CH.A. (2015): Wildland recreation. Wiley Blackwell, $3^{\text {rd }}$ edition.

HARDY, A., HYSLOP, S., BOOTH, K., ROBARDS, B., ARYAL, J., GRETZEL, U., ECCLESTON, R. (2017): Tracking tourists' travel with smartphone-based GPS technology: a methodological discussion. Information Technology \& Tourism, 17, 3, 255-274.

HÄGERSTRAND, T. (1970): What About People in Regional Science. In: Papers of the Regional Science Association 24, 7-21.

HIBNER, J., TACZANOWSKA, K., ZIĘBA, A., BRANDENBURG, CH., MUHAR, A., BALON, J. (2018): Visitor profiling for cable car mountain destinations as a basis for protected area management: a case study of the summer season in the Tatra Mountains at Kasprowy Wierch (Poland) and Skalnaté Pleso (Slovakia). Eco.mont, 10, 1, 24-35.

HRNČIAROVÁ, T. (2014): Load/Carrying Capacity of High Mountain Landscape by Hiking Trails - Methodology and Exampleof Evaluation in the Central Part of the Nízke Tatry Mts. Životné prostredie, 48, 4, 217-222.

KORPILO, S., VIRTANEN, T., SAUKKONEN, T., LEHVÄVIRTA, S. (2018): More than A to B: Understanding and managing visitor spatial behaviour in urban forests using public participation GIS, Journal of Environmental Management, 207, 124-133.

KRTIČKA, L., TOMČÍKOVÁ I., RAKYTOVÁ, I. (2018): Development versus conservation: evaluation of landscape structure changes in Demänovská Valley, Slovakia. Journal of Mountain Science 15, 6, 1153-1170.

KRUGER, M., VILJOEN, A., SAAYMAN, M. (2017): Who visits the Kruger National Park, and why? Identifying target markets. Journal of Travel and Tourism Marketing, 34, 3, 312-340.

MANNING, R.E., ANDERSON, L.A. (2012): Managing Outdoor Recreation. Case Studies in the National Parks. CABI.

MARIN, L.D., NEWMAN, P., MANNING, R., VASKE, J, STACK, D. (2011): Motivation and acceptability norms of human-caused sound in Muir Woods National Monument. Leisure Sciences, 33, 2, 147-161.

MARQUES, C., REIS, E., MENEZES, J. (2010): Profiling the segments of visitors to Portuguese protected areas. Journal of Sustainable Tourism, 18, 8, 971-996.

MAYER, M., MOSE, I. (2017): The opportunity costs of worthless land: The nexus between national parks and glacier ski resorts in the Alps. Eco.mont, 9, 35-45. 
MEIJLES, E.W., DE BAKKER, M., GROOTE, P.D., BARSKE R. (2014): Analysing hiker movement patterns using GPS data: Implications for park management. Computers environment and urban systems $47,44-57$.

NEEDHAM, M.D., ROLLINS, R.B., CEURVORST, R.L., WOOD, C.J.B., GRIMM, K.E., DEARDEN P. (2011): Motivations and Normative Evaluations of Summer Visitors at an Alpine Ski Area. Journal of Travel Research, 50, 6, 669-684.

OLIVEIRA, F., PINTASSILGO, P., PINTO, P., MENDES, I., SILVA, J. (2017): Segmenting visitors based on willingness to pay for recreational benefits: The case of Leiria National Forest. Tourism Economics, 23, 3, 680-691.

PEGG, S., PATTERSON, I., GARIDDO, P. (2012): The impact of seasonality on tourism and hospitality operations in the alpine region of New South Wales, Australia. International Journal of Hospitality Management, 31, 3,659-666.

PETROVIC, J., TOMICEVIC-DUBLJEVIC, J., STAVRETOVIC, N. (2016): Understanding Summer Visitors and Their Attitudes to the Kopaonik National Park, Serbia. Baltic Forestry, 22, $2,315-326$.

PETTERSSON, R., ZILLINGER, M. (2011): Time and space in event behaviour: Tracking visitors by GPS. Tourism Geographies, 13, 1, 1-20.

PICKERING, C., HARRINGTON, J., WORBOYS, G. (2003): Environmental Impacts of Tourism on the Australian Alps Protected Areas. Mountain Research and Development, 23, 3, 247-254.

PICKERING, C., ROSSI, S.D., HERNANDO, A., BARROS, A. (2018): Current knowledge and future research directions for the monitoring and management of visitors in recreational and protected areas. Journal of Outdoor Recreation and Tourism, 21, 10-18.

PISCOVÁ, V., HRNČIAROVÁ, T., HREŠKO, J., DOBROVODSKÁ, M., IZAKOVIČOVÁ, Z., IZSOFF, M., KALIVODA, H., KANKA, R., KENDERESSY, P., POVAŽAN, R., ROHÁČ, J., SLABEJOVÁ, M., SLIVINSKÝ, J., ŠPULEROVÁ, J., ŠVAJDA, J., TOPERCER, J., VLACHOVIČOVÁ, M., BOROVSKÝ, I., HURTA, V. (2018): Využívanie vysokohorskej krajiny a jeho dôsledky na zmenu prostredia (na príklade Tatier a Nízkych Tatier). Vydavatel'stvo SAV VEDA, Bratislava, $250 \mathrm{pp}$. (Utilization of high mountain landscape and its impacts on change of environment in Tatras and Low Tatras. In Slovak).

RICHINS, H., HULL, J., eds. (2016): Mountain Tourism: Experiences, Communities, Environments and Sustainable Futures. Wallingford, Oxfordshire; Boston, MA: CABI.

SATOMURA, M., SHIMADA, S., GOTO, Y., NISHIKORI, M. (2005): GPS measurements to investigate the reason why GPS is less accurate in mountain areas. In A Window on the Future of Geodesy, Springer, Berlin, Heidelberg, 44-47.

SCHAMEL, J. (2017): A demographic perspective on the spatial behaviour of hikers in mountain areas: The example of Berchtesgaden National Park. Eco.mont, 9, 66-74.

SHOVAL, N., ISAACSON, M. (2007): Tracking tourists in the digital age. Annals of Tourism Research, 34, 1, 141-159.

SHOVAL, N., ISAACSON, M., CHHETRI, P. (2013): GPS, smartphones, and the future of tourism research. The Wiley Blackwell companion to tourism, 251-261.

SHOVAL, N., Mc KERCHER, B., BIRENBOIM, A., NG, E. (2015): The application of a sequence alignment method to the creation of typologies of tourist activity in time and space. Environment and Planning B: Planning and Design, 42, 1, 76-94.

SHOVAL, N., AHAS, R. (2016): The use of tracking technologies in tourism research: the first decade. Tourism Geographies, 18, 5, 587-606.

SIRAKAYA-TURK, E., UYSAL, M.S., HAMMIT, W.E., VASKE, J.J. (2017): Research Methods for Leisure, Recreation and Tourism. CABI. 
STAMBERGER, L., VAN RIPER, C.J., KELLER, R., BROWNLEE, M., ROSE, J. (2018): A GPS tracking study of recreationists in an Alaskan protected area. Applied Geography 93, 92-102. ŠPULEROVÁ, J., HRNČIAROVÁ, T., PISCOVÁ, V., VLACHOVIČOVÁ, M., KALIVODA, H. KANKA, R., DOBROVODSKÁ, M., KENDERESSY, P., MIKLOŠOVÁ, V., DRÁBOVÁ, M., BELCÁKOVÁ, I. (2016): Sustainable tourism development in a selected area of the Low Tatras National Park - landscape planning versus urban planning. Carpathian Journal of Earth and Environmental Sciences, 11, 2, 485-496.

TACZANOWSKA, K., MUHAR, A., BRANDENBURG, C. (2008): Potential and limitations of GPS tracking for monitoring spatial and temporal aspects of visitor behaviour in recreational areas. In: Raschi, A., Trampetti, S. (eds): Proceedings of the Fourth International Conference on Monitoring and Management of Visitor Flows in Recreational and Protected Areas. Montecatini Terme 14-19 Oct. 2008, 451-456.

TACZANOWSKA, K., GONZÁLEZ, L.-M., GARCIA-MASSÓ, X., MUHAR, A., BRANDENBURG, C., TOCA-HERRERA, J.-L. (2014): Evaluating the structure and use of hiking trails in recreational areas using a mixed GPS tracking and graph theory approach. Applied Geography, 55, 184-192.

TACZANOWSKA, K., ZIĘBA, A., HIBNER, J., MAKARUK, W., BRANDENBURG, CH., MUHAR, A., LATOSIŃSKA, B., PREISEL, H., GONZÁLEZ, L.M., GARCÍA, X., TOCAHERRERA, J.L., ZIOBROWSKI, S. (2016): Application of GPS-tracking to analyse the spatial behaviour of cable car users - a case study from the summer season in the Tatra NP, Poland. Monitoring and Management of visitors in recreational and protected areas. Abstract book. University of Novi Sad, Serbia. 263-266.

TOBLER, W. (1970): A computer movie simulating urban growth in the Detroit region. Economic Geography, 46 (Supplement): 234-240.

TSIARAS, S. (2017): Exploring the impact of tourism to the sustainable development of mountain regions: Implications of the climatic conditions. International Journal of Agricultural and Environmental Information Systems, 8, 1, 14-28.

WOLF, I.D., HAGENLOH, G., CROFT, D.B. (2012): Visitor monitoring along roads and hiking trails: How to determine usage levels in tourist sites. Tourism Management, 33, 1, 16-28.

WORBOYS, G.L., LOCKWOOD, M., KOTHARI, A., FEARY, S., PULSFORD, I., eds. (2015): Protected Area Governance and Management, ANU Press, Canberra.

\section{ACKNOWLEDGEMENT}

Authors would like to thank the Low Tatras NP Administration for overall support of survey and to all people involved in the field work. We are grateful to the Tatra NP Administration in Poland for lending GPS-loggers and the cable car operator (Tatra Mountain Resort) for sharing data. Acknowledgements for technical support to the Center for Geoinformatics and Digital Technologies (Faculty of Natural Sciences MBU) and CEEPUS programme for supporting teaching mobility as well students from the University of Natural Resources and Life Sciences in Vienna (BOKU): Friedrich Knopper, Thomas Banczi, Maria-Theresia Fischer, Adam Strof, Lukas Svirak, Stefan Jekel for their work and involvement during GIS-supported project. Finally we also wish to thank anonymous reviewers and editors who provided many helpful suggestions for substantial improvements of the manuscript. 